\title{
Evaluation of common quince of VNIISPK breeding as pear seedling rootstock for fruit production in Central Russia
}

\author{
Igor Semin*, Evgeniy Dolmatov, and Zoya Ozherelyeva \\ All-Russian Research Institute of Fruit Crop Breeding (VNIISPK), Zhilina village, Oryol, Oryol \\ region, Russian Federation
}

\begin{abstract}
The article presents preliminary results of studies on the assessment of VNIISPK breeding common quince use as an intensive type seedling rootstock for pear cultivation in the conditions of Central Russia. It was established that the common quince of VNIISPK breeding is suitable to be used as seedling rootstock of pear in conditions of the Russian midland and has sufficient winter resistance of overground and root systems, high seedling yield in seedling rootstock breeding and good compatibility with some pear varieties. Strong fusion with the rootstock and active growth development when using an apple-pear hybrid No. 818 was noted; it can be recommended as an intermediate stock (mediator) in incompatible variety-rootstock combinations. Research in this direction will be continued.
\end{abstract}

\section{1 introduction}

As it is known, there are practically no industrial pear plantations in Central Russia [1]. One of the main reasons is the lack of a suitable intensive type rootstock able to increase the productivity of plantings [2]. To date, the only roostock used in the zone is the wild pear (R. pyraster); it does not meet the requirements of modern horticulture by a number of indicators. It has a rod-shaped root system with weak regeneration; leaves are often affected by diseases (up to 5 points in epiphytotic years), varieties grafted on it show strong growth and late fruiting start, plantings on this roostock are often not productive enough. [3]. VNIISPK considers the use of common quince as one of the ways to solve the problem; it has been widely used in world fruit growing as an intensive pear rootstock, but in Russia its distribution has always been limited by insufficient plants' winter resistance $[4 ; 5 ; 6]$. However, in recent years as a result of breeding work with selected forms of common quince, breeder E.A. Dolmatov with a group of employees obtained forms of dwarf winterresistant rootstocks capable of vegetative reproduction with green cuttings, high seed productivity and good compatibility with varieties of pear in the nursery $[7 ; 8]$. In world practice, seedlings on clone rootstock are widely used for establishing an orchard, which allows to obtain genetically homogeneous plantings according to a number of economic traits (plant height, size and quality of fruits, etc.). However, in fact, rootstocks' seed

${ }^{*}$ Corresponding author: semin@vniispk.ru 
reproduction is easier, cheaper and faster and allows to obtain a greater yield of planting material of the desired quality in a similar period of time. In addition, thanks to stronger root system, gardens on seedling rootstock most often do not require support structures unlike clones that have weak anchor roots [8].

In this regard, the aim of our work was to evaluate VNIISPK breeding common quince on suitability as seedling rootstocks (as an alternative to clones) for the production of pear fruits in conditions of Central Russia.

\section{Materials and methods}

The object of research was the VNIISPK breeding common quince seedling obtained from selected forms, which showed the ability to tolerate climatic conditions of the midland of Russia for 20 years. The method of research consisted of observations and records carried out with objects of research on grafters in the grafting and seedling garden, in nursery conditions and in laboratory conditions on the basis of FSBSI VNIISPK. Work with common quince seedlings was carried out using greenhouses without shelter (artificial rows) and in the field. Research on frost resistance of common quince seedlings' root system and annual growth was carried out together with the staff of the laboratory of fruit plants' stability physiology by artificial freezing method under controlled conditions. All records and observations were carried out in accordance with the "Program and methods of variety study, fruit, berry and nut crops" (Oryol, 1999); the accelerated assessment method of fruit and berry plants' winter resistance" (Tyurina, Gogoleva, 1978). The frost resistance assessment of annual growth was done by the degree of wood freezing on a five-point scale. Artificial freezing was carried out in the climatic chamber "ESPEC" PSL - 2CRN (with temperature range of $-70 \ldots+1500 \mathrm{C}$ and adjustable humidity). The program considers four components of winter resistance: -Formation of frost resistance or resistance

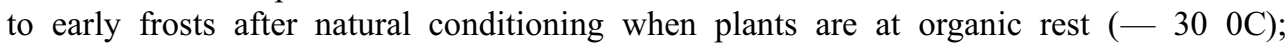
Maximum frost resistance (the period of organic rest end ( $-400 \mathrm{C}$ ); Retention of frost resistance during thaw (state of forced rest $(-250 \mathrm{C})$ and the ability to restore frost resistance during repeated conditioning after thaw (in a state of forced rest ( $-350 \mathrm{C}$ ).

\section{Results and discussion}

\subsection{Morpho-biological features of common quince}

VNIISPK breeding common quince grows in the form of a multi-stem bush $300-330 \mathrm{~cm}$ high with medium and strong shoot formation ability (Figure 1). In the conditions of the Oryol region, flowering usually occurs in the II and III decade of May, which makes it possible to avoid returning frost. For all the years of observation (except 2010 and 2013, when the adverse weather conditions of the growing season were in effect), quince showed high cuttings and seedlings productivity, as well as resistance to disease.

Common quince is a thermophyte and by nature usually grows in regions with mild climates. In the climatic conditions of Central Russia, observation of the passage of plant development phenological phases showed that buds' swelling and blossoming occurred 2-4 days earlier than that of pear. This is probably due to the biological features of common quince, which requires smaller sum of positive temperatures to resume vegetation compared to pear. There were no significant differences between plants of different forms of common quince revealed. There was a negative effect on yield formation and the duration of fruit ripening caused by a lack of moisture against the high temperatures background in July-August. Thus, in 2019 ripening was stretched and lasted from the 2nd 
decade of September to the 3rd decade of October, that is, about 50 days. The high fruit cast in August led to a 10-15\% decrease in yields. In 2020, fruit ripening was more uniform and lasted for about 30 days; fruit cast reduced the yield by $8-12 \%$.

Field observations on the plants' condition and the records carried out to assess the winter resistance of common quince, showed good results. Given the relatively mild conditions of the 2018-2019 winter period relatively with long-term observations, plants overwintered without serious damage (table 1). Weak ice scalds (not more than 1 point) were observed on surface tissues and most likely were obtained in the second half of winter, when the plants got saturated with moisture and were not able to resist temperature change after thaw. However, in general, the plants recovered well during the season.

Table 1. Estimation of common quince's winter resistance in the field (visual method) and in laboratory conditions (method of annual growth's artificial freezing)

\begin{tabular}{|c|c|c|c|}
\hline & $\begin{array}{l}2018- \\
2019\end{array}$ & $\begin{array}{l}2019- \\
2020\end{array}$ & $\begin{array}{l}\text { Averag } \\
\text { e for } 2 \\
\text { years }\end{array}$ \\
\hline \multicolumn{4}{|l|}{ Visual evaluation method } \\
\hline Degree of bark subfreezing, score & 1 & 0 & 0.5 \\
\hline Wood subfreezing, score & 0 & 0 & 0.0 \\
\hline Frost injury of crown branches, score & 1 & 0 & 0,5 \\
\hline General degree of freezing, score & 1 & 0 & 0.5 \\
\hline \multicolumn{4}{|l|}{ Laboratory evaluation method } \\
\hline $\begin{array}{l}\text { The temperature of artificial freezing by } 4 \text { components of } \\
\text { winter resistance - } \\
1 \mathrm{~K}-30^{\circ} \mathrm{C} \text { : } \\
2 \mathrm{~K}-40^{\circ} \mathrm{C} \text { : } \\
3 \mathrm{~K}-25^{\circ} \mathrm{C} \text { : } \\
4 \mathrm{~K}-35^{\circ} \mathrm{C}\end{array}$ & $\begin{array}{ll}0.8 & : \\
3.6 & : \\
2.7 & : \\
4.4 & \\
\end{array}$ & $\begin{array}{ll}1.1 & : \\
4.0 & : \\
2.2 & : \\
4.0 & \end{array}$ & $\begin{array}{l}1.1: \\
3.8: \\
2.5: \\
4.2\end{array}$ \\
\hline
\end{tabular}

The winter of 2019-2020 was characterized by unusually warm periods and rather long low positive temperatures, as well as a small amount of precipitation. There were no typical frosts of the Russian midland climatic conditions in 2019-2020. As a result, all plants had healthy appearance and normal regrowth without symptoms of damage by adverse winter period factors and flowered more profusely than ever.

Artificial freezing of common quince shoots in controlled conditions, comparable to the critical temperatures of the winter period of the Russian midland showed minor damage in early winter, when after autumn conditioning quince plants can tolerate a decrease in air temperature to $-30^{\circ} \mathrm{C}$ and in the middle of winter - to $-25^{\circ} \mathrm{C}$. (table 1). More significant damage was obtained during freezing for maximum frost resistance at $-40^{\circ} \mathrm{C}$ and on the ability to restore quince's frost resistance during repeated conditioning $-35^{\circ} \mathrm{C}$ after late winter thaw. During this period, quince plants are most vulnerable and can freeze, but in practice harsh winters in temperate latitudes are rare.

\subsection{Common quince productivity}

During the last 2 years in grafting and seedling plantations, there was no damage by the winter period's unfavorable factors. In 2020, the flowering of quince was as complete as possible. However, due to adverse weather conditions of the growing season in the springsummer period, quince's fruiting is much lower than in the number of previous years (Table 2). During the growing season, plants experienced a lack of moisture (May-June 2019 and May 2020), which eventually led to premature fruit cast. Therefore, the actual yield was lower than expected. July 2019 precipitation contributed to an increase in the average size 
of common quince fruit, seeds number per fruit and the average obtained seeds weight (Table 2). Lack of moisture in July and August 2020 had an impact on the decline of these indicators.

When extracting seeds from the fruit, the proportion of full seeds is more than $90 \%$ (according to 2018 data -92-96\%). Figures 2 and 3 show the seed productivity of common quince in comparison with wild pear. The advantages are obvious - 1 quince fruit can give an average of 57.6 seeds, a pear - 8-12 seeds. At the same time, the actual common quince yield is always higher than that of pear; its proportion of full seeds reaches 90 and more \%, and in pear fruits - no more than $50-60 \%$. In general, the common quince's seed productivity is 5-6 times higher than that of pear.

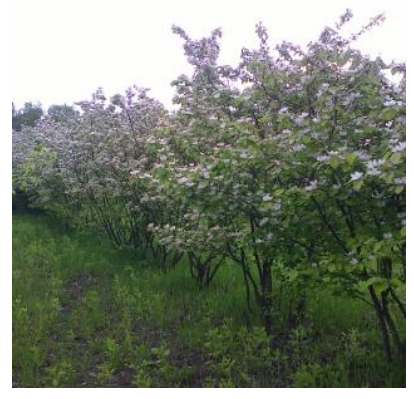

Fig. 1. Common quince type of VNIISPK breeding

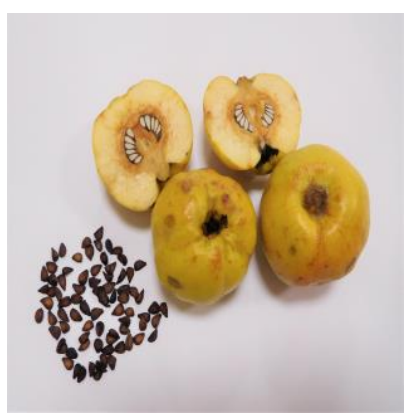

Fig. 2. Fruit and seeds of common quince

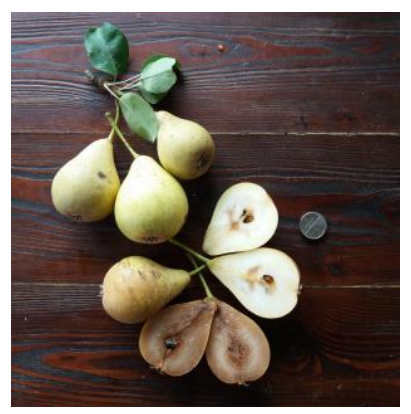

Fig. 3. Fruits and seeds of wild pear

Common quince seeds extracted from a fruit are covered with a special ambient substance - mucus, which swells when moistened and becomes a significant obstacle in working with seeds. To facilitate the process, mucus must be removed. In order to establish how much mucus is contained in the seeds, approximately $150 \mathrm{~g}$ of common seeds taken from the quince's fruits (Table 2) was weighed. Then the seeds were soaked in water for a 
day and swollen mucus was rinsed off. Further, the seeds were dried in room conditions and weighed again. According to the weight difference, the percentage of mucus was determined. As a result of the studies, it was possible to establish that mucus can average up to $30-40 \%$ of the weight of seeds extracted from the fruits.

Table 2. Yield and seed productivity of selected forms of common quince in the conditions of Central Russia.

\begin{tabular}{|c|c|c|c|c|c|c|c|c|c|}
\hline 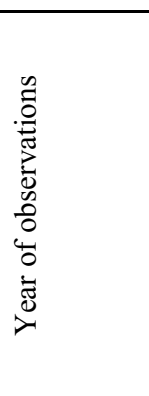 & 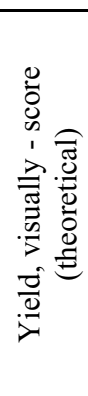 & 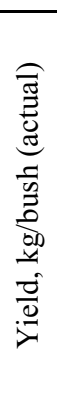 & 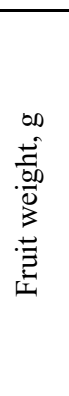 & 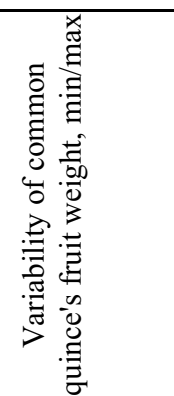 & 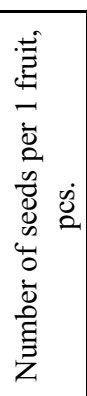 & 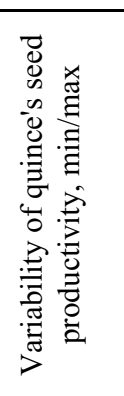 & $\begin{array}{l}00 \\
\tilde{8} \\
0 \\
8 \\
\infty \\
8 \\
8 \\
0 \\
4 \\
0 \\
\frac{0}{00} \\
\frac{00}{0} \\
3\end{array}$ & 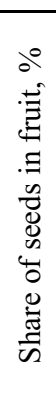 & 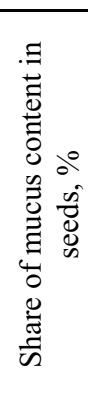 \\
\hline $2008-2009$ & - & 5.5 & 52.4 & - & 54.3 & - & - & - & - \\
\hline 2018 & - & 1.2 & 49.1 & $29.6 / 86.3$ & 57.8 & $10 / 128$ & 21.6 & 5.1 & 30.4 \\
\hline 2019 & 5 & 4.3 & 84.4 & $61.9 / 128.7$ & 60.4 & $14 / 132$ & 22.7 & 6.4 & 32.6 \\
\hline 2020 & 4 & 3.8 & 60.3 & $32.1 / 100.3$ & 54.7 & $6 / 118$ & 22.2 & 4.9 & 36.6 \\
\hline average & 3.7 & 3.1 & 64.6 & $41.2 / 105.1$ & 57.6 & $10 / 126$ & 22.2 & 5.5 & 33.2 \\
\hline
\end{tabular}

\subsection{Sowing qualities of rootstock seeds}

Research on the seeds' germination was carried out in laboratory conditions, as well as on the basis of a nursery using "artificial rows" (greenhouses) in 2019-2020 and in the field condition on the selection nursery garden plot. In germination of common quince seeds, germination was more than $95 \%$ at the end of the stratification period. Then germination decreases due to damage and death of primary roots from excess moisture, lack of oxygen and nutrients. Direct sowing showed that the denser the sowing, the higher the seeds germination and the higher yield of seedlings (Table 3 ). The greatest germination was noted when using artificial rows.

Speaking about the seedlings' nutrition area during the cultivation of rootstock, it was established that the best results are obtained when sowing according to the $0.5 \mathrm{~cm} \mathrm{x} 20 \mathrm{~cm}$ scheme (Table 3). When using "artificial rows", the seeds' germination and the quality of seedlings is higher than in plants grown in the field; with this, the advantage of a very high material yield from a unit of cultivated area should be noted, unlike cultivation in the field. In studies using "artificial rows", there is a higher germination and short expectancy when sowing sprouted seeds (table 4). The seedlings' yield in the seeds sowing options with 3-5 $\mathrm{mm}$ roots was the highest compared to the rest of the options. However, with the abuse of seeds' germination that formed a hypocotyl or primary root, further sprouts' development is not always advisable, since there is an appearance of secondary roots and a significant decrease in germination due to the death of suction roots because of excess moisture, lack of oxygen and nutrients. 
Table 3. Germination of common quince seeds with different spacing area

\begin{tabular}{|l|l|l|l|}
\hline $\begin{array}{l}\text { Planting scheme } \\
\mathrm{cm} \times \mathrm{cm}\end{array}$ & $\begin{array}{l}\text { Germination } \\
\text { (act.), \% }\end{array}$ & $\begin{array}{l}\text { Planting scheme } \\
\mathrm{cm} \times \mathrm{cm}\end{array}$ & $\begin{array}{l}\text { Germination } \\
\text { (act.), \% }\end{array}$ \\
\hline Artificial rows & Field-planting & 56.5 \\
\hline $0.5 \times 20$ & 77.0 & $0.5 \times 20$ & 19.5 \\
\hline $1.5 \times 20$ & $1.5 \times 20$ & 0 \\
\hline $3.0 \times 20$ & $3.0 \times 20$ & 97.3 \\
\hline \multicolumn{2}{|l}{ Laboratory germination, \% } & \\
\hline
\end{tabular}

Table 4. Determination of the optimal quince seeds' sowing period after stratification.

\begin{tabular}{|l|l|l|}
\hline Option & Germination, \% & Shoots expectancy, days \\
\hline $\begin{array}{l}\text { The seed's white root hull is not visible, } \\
\text { but the term of stratification ends. }\end{array}$ & 40 & 7 \\
\hline $\begin{array}{l}\text { Seed's white root hull is visible (tubercle } \\
\text { less than 1 mm) }\end{array}$ & 60 & 4 \\
\hline $\begin{array}{l}\text { Seeds began to germinate. Seed's white } \\
\text { root hull is visible }(3-5 \mathrm{~mm})\end{array}$ & 73 & 2 \\
\hline
\end{tabular}

\subsection{Output and some rootstock quality indicators}

To determine the quality of the obtained common quince seedlings in the conditions of "artificial rows", seeds were sown in the nursery according to a $0.5 \mathrm{~cm}$ x $20 \mathrm{~cm}$ scheme. Repeatability was triple; the rows were located in different places of the greenhouse and on the site of the breeding nursery garden against the background of the total weight of common quince's sown seeds. Studies have shown that on average for 2 years with the use of "artificial rows", the actual germination of common quince can amount to $78 \%$ (Table 5). Rootstocks have an average of $21 \mathrm{~cm}$ growth, 3.3 skeletal roots $14 \mathrm{~cm}$ long and a root neck thickness of $4.5 \mathrm{~mm}$. However, with improved nutritional conditions and moisture, these indicators can improve significantly.

Table 5. Quality of common quince rootstock when sowing in the field and in conditions of "artificial rows" $(2019 ; 2020)$

\begin{tabular}{|l|l|l|l|l|l|l|}
\hline \multirow{2}{*}{ Parameters } & \multicolumn{3}{l}{ In the field } & \multicolumn{2}{l|}{ In the conditions of artificial rows } \\
\cline { 2 - 8 } & 2019 & 2020 & average & 2019 & 2020 & average \\
\hline Germination, \% & 44.1 & 31.0 & $\mathbf{3 7 . 6}$ & 65.0 & 92.3 & $\mathbf{7 8 . 7}$ \\
\hline Growth length, cm & 12.4 & 9.2 & $\mathbf{1 0 . 8}$ & 17.6 & 24.4 & $\mathbf{2 1 . 0}$ \\
\hline Number of skeleton roots, pcs & 2.2 & 1.4 & $\mathbf{1 . 8}$ & 3.5 & 3.1 & $\mathbf{3 . 3}$ \\
\hline Length of skeleton roots, cm & 9.0 & 6.2 & $\mathbf{7 . 6}$ & 12.0 & 15.9 & $\mathbf{1 4 . 0}$ \\
\hline Skeleton root thickness, mm & 1.3 & 1.0 & $\mathbf{1 . 2}$ & 2.7 & 2.6 & $\mathbf{2 . 6}$ \\
\hline Branching order & 2.0 & 1.4 & $\mathbf{1 . 7}$ & 3.2 & 2.8 & $\mathbf{3 . 0}$ \\
\hline Thickness of root neck, mm & 3.1 & 2.5 & $\mathbf{2 . 8}$ & 4.5 & 4.0 & $\mathbf{4 . 5}$ \\
\hline
\end{tabular}

On average, the studies also found that $60-65 \%$ of seedlings were in the same range of annual growth height $(20-30 \mathrm{~cm})$ and root length $(12-16 \mathrm{~cm})$, which characterizes the percentage of rootstock material leveling. The remaining 40 were distributed between more than $30 \mathrm{~cm}(12-15 \%)$ and less than $20 \mathrm{~cm}(20-25 \%)$ of growth.

Quality indicators were much higher in seedlings grown in "artificial rows" conditions. The length of seedlings' roots was on average about $50 \%$ of the annual growth. Annual growth branching was practically absent. Each seedling has fairly branched roots (the 3rd order of branching starting from skeletal), which characterizes the presence of a large number of suction roots and favorably affects habitability and rootstock's nutritional 
conditions. The thickness of the root neck is $4.5 \mathrm{~mm}$. The development and preservation of common quince's seedlings is significantly influenced by moisture conditions during the growing season and the breathability of the soil or substrate in which they are grown. This is due to the superficial and very branched root system of rootstocks.

\subsection{Frost resistance of the root system of annual common quince seedlings}

Unlike pear, common quince has a branched surface root system, so the assessment of roots' frost resistance is important. In the field, annual quince seedlings planted in the soil since autumn had a small percentage of fallout and grew well in spring. To determine the maximum frost resistance, studies were carried out by the method of artificial freezing of seedlings under controlled conditions. Seedlings of common quince and pear (control comparison) were exposed to temperatures - $90 \mathrm{C}$; $-100 \mathrm{C}$ and $-110 \mathrm{C}-120 \mathrm{C}$. Such temperatures were chosen for a reason. The basis was the data of previous studies [7] and perennial weather and climatic conditions in the Oryol region in recent years. As a result, it was found that quince and pear plants had the least degree of damage when exposed to a temperature of $-90 \mathrm{C}$ (Table 6). The greatest damage was noted in plants when exposed to a temperature of $-11-120 \mathrm{C}$. The nature and degree of damage to the roots decreases with an increase in their thickness. Skeletal roots of more than $4 \mathrm{~mm}$ were virtually undamaged or had minor damage. Subtle roots of different arrangement orders were damaged the most. However, in all studied forms of VNIISPK breeding common quince, the ability of the root system to tolerate critical temperatures of the winter period at the wild pear seedlings' level and recover well when cultivated was noted with artificial freezing. With this, quince showed a higher regeneration capacity than pear, since with slightly stronger root tissue damage (-11-12 0C) quince is earlier and more active to built up shoots and younger roots compared to pear seedlings.

Table 6. Root system frost resistance of common quince seedlings (degree of damage, average score considering conditional coefficients (Vekhov, 1999)) Average for 2019-2020 of research

\begin{tabular}{|l|l|l|l|l|l|}
\hline \multirow{2}{*}{ crop } & \multicolumn{5}{|l|}{ Freezing temperature } \\
\cline { 2 - 6 } & $\begin{array}{l}\text { Control (without } \\
\text { freezing) }\end{array}$ & $\mathbf{- 9} \mathbf{~}^{\mathbf{0}} \mathbf{- 1 0}{ }^{\mathbf{0}} \mathbf{C}$ & $\mathbf{- 1 1} \mathbf{}^{\mathbf{C}}$ & $\mathbf{- \mathbf { 1 2 } ^ { \mathbf { 0 } } \mathbf { C }}$ \\
\hline Common quince & 0 & 0.5 & 9.6 & 16.8 & 28.1 \\
\hline Wild pear & 0 & 0 & 3.8 & 10.0 & 18.7 \\
\hline Excluding notional coefficients (Budagovsky, $\mathbf{1 9 6 8})$ \\
\hline Common quince & 0 & 0.5 & 1.5 & 2.1 & 2.9 \\
\hline Wild pear & 0 & 0 & 0.6 & 1.7 & 2.6 \\
\hline
\end{tabular}

\subsection{Compatible with varieties and forms of pear}

Quince and pear belong to different families, so there is a frequent phenomenon of componentsэ incompatibility at grafting. Incompatibility traits can manifest already in the nursery. First of all, variety fusion with the rootstock is determined by three main indicators [11]: Point disease - manifests in the form of weak growth, small dry leaves and the apparent formation of necrosis in wood and on the bark of rootstock; rootstock starvation manifests itself slightly later than point disease and is expressed in relatively early end of the progressive shoots' growth, premature redness and leaf fall; the third indicator is manifested by the formation of an influx at the fusion of graft and rootstock and an insecure connection of graft and rootstock at the grafting point. The trait may not manifest itself immediately and plants can at first show relatively strong and good growth. However, after a while, shoots can break off and fracture would be smooth without fibers. 
In preliminary studies in the nursery, the employees of VNIISPK established good compatibility of common quince with seed rootstocks of 6 pear varieties having industrial importance for fruit production by intensive technologies: Alaya, Belarusskaya pozdnyaya, Yeseninskaya, Muratovskaya, Pamyati Yakovleva, Tyutchevskaya, etc. [8]. Good fusion with the rootstock and active progressive graft growth were noted in the nursery. Varieties Annushka and Pamyatnaya had strong fusion with rootstock and showed no obvious signs of incompatibility, but there was no single standard seedling obtained in the grown seedlings' batch mainly due to low values of annual growth (Table 7). On the contrary, Chizhovskaya and Krasavitsa Chernenko varieties had an active progressive growth of shoots at the beginning of vegetation, which significantly weakened after mid-summer lignification beginning compared to other varieties and options with pear rootstock. Perhaps these varieties have partial incompatibility, when due to differences in biological structure or metabolism individual tissues cannot fully fuse together, which leads to violation of physiological processes in plants' development. Therefore, despite the intensive growth of Chizhovskaya and Krasavitsa Chernenko, those varieties showed a good result, but unlike the rest of the combinations, the development on the pear rootstock was much stronger than on quince.

Table 7. Compatibility of common quince with pear varieties [8; 12]

\begin{tabular}{|l|l|l|}
\hline $\begin{array}{c}\text { Well-compatible } \\
\text { varieties and forms of } \\
\text { pear }\end{array}$ & $\begin{array}{c}\text { Satisfactory } \\
\text { compatibility of pear } \\
\text { varieties and forms }\end{array}$ & $\begin{array}{c}\text { Incompatible varieties } \\
\text { and forms of pear }\end{array}$ \\
\hline $\begin{array}{l}\text { Yeseninskaya } \\
\text { Tyutchevskaya }\end{array}$ & Annushka & Orlovsaya krasavitsa \\
Muratovskaya & Pamyatnaya & Orlovskaya letnyaya \\
Alaya & Chizhovskaya & Skorospelka iz \\
Pamyati Yakovleva & Krasavitsa Chernenko & Michurinska \\
Belarusskaya pozdnyaya & & Rusanovskaya \\
$\begin{array}{l}\text { Interstock - apple-pear } \\
\text { hybrid No. 818 }\end{array}$ & & Interstock - Ussurian pear \\
& & seedling No. 20-11 \\
\hline
\end{tabular}

Obvious signs of incompatibility were noted when grafting on quince varieties of pears Oryol beauty, Oryol summer, Skorospelka from Michurinsk, Rusanovskaya (Figure 7; 8; 9) and winter-resistant apomictic seedler Pear Ussuri origin No. 20-11, which was considered as an insertion rootstock (tab 7). In these combinations, there were influxes and breakages in the place of rootstock fusion, premature change in leaves' color and their early fall, as well as intensive underbush formation in the rootstock zone. Often, the graft bark changed the color by acquiring shades of red immediately after shoots' lignification in the middle of summer and was phenotypically different from the original. There was an oppression of plants compared to combinations when using pear rootstock. Obviously, these varieties need a mediator (interstock) when grafted on common quince.

Apple-pear hybrid No. 818 showed the best fusion with common quince and intensive growth, as well as very active branching throughout the growing season and can be considered as compatible interstock (mediator) for pear varieties incompatible with common quince (Figure 6). In addition, the hybrid itself is a stocky rootstock and has a fairly high winter resistance in the middle region of Russia. 


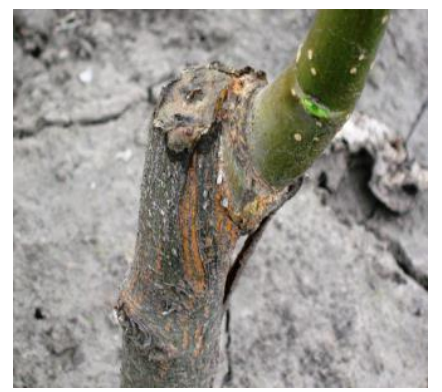

Fig. 4. Yeseninskaya on quince

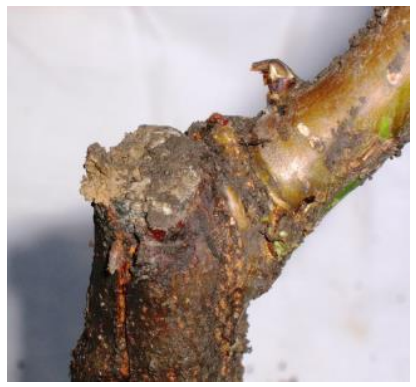

Fig. 5. Muratovskaya on quince

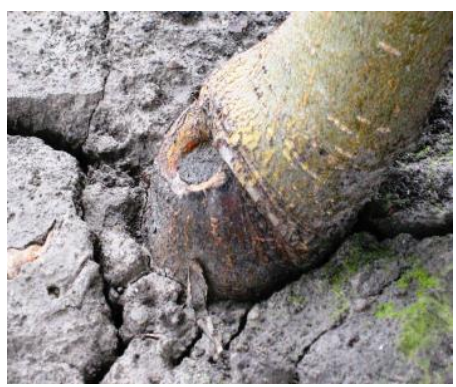

Fig. 6. Apple-pear hybrid No. 818 on quince

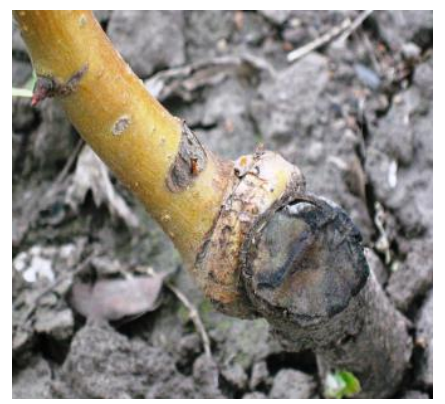

Fig. 7. Orlovsaya krasavitsa on quince 


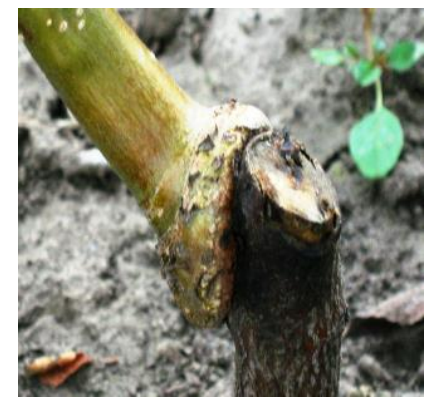

Fig. 8. Orlovskaya letnyaya on quince

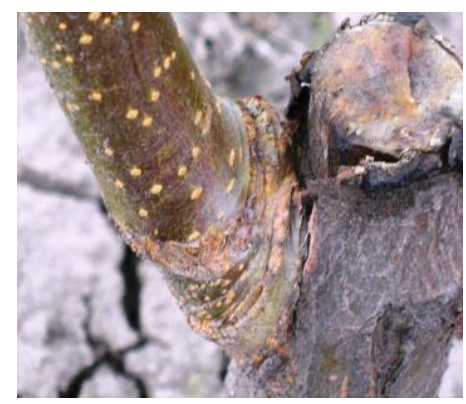

Fig. 9. Rusanovskayaon quince

\section{Conclusion}

The studies have shown that VNIISPK breeding common quince has high seedling productivity, seed germination, yield and quality of rootstocks in the nursery conditions and has sufficient winter resistance and frost resistance of the above-ground and root systems of rootstocks. Research in this direction will continue, but it is already possible to point out the wide prospects of using VNIISPK breeding common quince as a seedling pear rootstock for fruit production by intensive technologies in conditions of the Russian midland.

\section{References}

1. R.D. Isaev, D.V. Sergeev, D.V. Gryaznev, Achievement of science and technology of AIC, 2, 29 (2009)

2. A.A. Fakhrutdinov, Improvement of the quality of pear seedling rootstocks: thesis abstract of Candidate of Agricultural Sciences, 28 (2005)

3. A.N. Polyakov, Improvement of pear rootstock in the conditions of the Central Chernozem region: thesis abstract... Candidate of Agricultural Sciences, 25 (2000)

4. S.N. Stepanov, Coll. of scientific articles, 7 (1973)

5. H. Jacob, Pyrodwarf: A new clonal rootstock for high density pear orchards, 38, 166 (1996)

6. E.Z. Savin, G.R. Mursalimova, N.A. Degtyarev, Bulletin of Orenburg State University, 12(94), 20 (2008)

7. O.N. Borisova, E.A. Dolmatov, Advances of modern science, 7, 11 (2017)

8. I.V. Semin, E.A. Dolmatov, Z.E. Ozherelyeva, Vegetables of Russia, 5, 75 (2020) 
9. T. P. Ogoltsova, Program and methodology of variety study of fruit, berry, and nut crops, 608, (1999)

10. M.M. Tyurina, Accelerated assessment of winter resistance of fruit and berry plants, methodical recommendations, 48 (1978)

11. V.A. Korovin, Causes of incompatibility in grafting of fruit plants, Compatibility of graft and rootstock of apple trees, 3 (1979)

12. O.N. Borisova, E.A. Dolmatov, Selection and variety breeding of garden crops, 3(2), 6 (2016) 